Gut, 1961, 2, 40

\title{
The effect of phenylbutazone (Butazolidin) on plasma pepsinogen activity
}

\author{
K. D. MUIRDEN \\ From the University of Melbourne, Department of Medicine at the Royal Melbourne \\ Hospital, Australia
}

SYNOPSIS Phenylbutazone in moderate dosage has been administered to 15 patients with a variety of musculo-skeletal disorders. A rise in plasma pepsinogen activity occurred in 13, generally reaching a peak in the first week of treatment; subsequently there was a fall in spite of maintaining a constant dosage. In four of six patients an anticholinergic drug failed to prevent a rise in plasma pepsinogen activity.

These findings are considered in relation to clinical observations on the time of appearance of gastrointestinal side-effects in patients receiving phenylbutazone.

The interpretation of the findings is discussed, and it is suggested that the rise in plasma pepsinogen activity induced by phenylbutazone may reflect either increased peptic activity in the stomach or a damaging effect of the drug on the stomach.

Phenylbutazone is a synthetic pyrazolone compound resembling aminopyrin in chemical structure. It is widely used in the treatment of arthritis and musculoskeletal disorders as it has analgesic and antiinflammatory properties.

Among its several side-effects, those on the gastrointestinal tract are particularly common. Although stomatitis, constipation, and diarrhoea may occur, the most frequent complaints are of epigastric discomfort and nausea (Kuzell, Schaffarzick, Naugler, Gaudin, and Mankle, 1953). These symptoms may be associated with reactivation of peptic ulcers, and such lesions may be complicated by haemorrhage or perforation (Kirsner, 1957). Multiple superficial ulcers in the stomach have also been reported (Dilling, 1953). On the other hand, no lesion may be detectable in the stomach to account for the symptoms.

There have been few studies of the mechanisms by which phenylbutazone provokes epigastric discomfort and peptic ulceration. Kirsner and Ford (1955) showed that the secretion of acid rose significantly in 30 of 57 studies in $\mathbf{4 9}$ patients with single doses of 200 to $600 \mathrm{mg}$. Phenylbutazone intramuscularly in single doses of 50 to $400 \mathrm{mg}$. increased gastric acidity in 10 of 30 studies on 29 patients. These results have been confirmed by Bellomo and Fusco (1956). Neither the effect of repeated doses of phenylbutazone on gastric acidity in man nor its effect on peptic cell activity appears to have been investigated.

This investigation is concerned with the effect of repeated doses of phenylbutazone on plasma pepsinogen activity in man.

\section{METHODS AND MATERIALS}

Phenylbutazone was first given to nine women with various musculo-skeletal disorders (Table I). Patient 6

TABLE I

PATIENTS TREATED WITH PHENYLBUTAZONE

\begin{tabular}{|c|c|c|}
\hline $\begin{array}{l}\text { Age } \\
\text { in } \\
\text { Years }\end{array}$ & Diagnosis & $\begin{array}{l}\text { Duration } \\
\text { of } \\
\text { Treatment } \\
\text { in Days }\end{array}$ \\
\hline
\end{tabular}

Patient 1 (L.W.)

Patient 2 (M.M.)

Patient 3 (L.L.)

Patient 4 (H.S.)

Patient 5 (Y.B.)

Patient 6 (A.M.)

Patient 7 (J.McN.)

Patient 8 (J.M.)

Patient 9 (D.A.)

$\begin{array}{llr}19 & \text { Sacro-iliac strain } & 7 \\ 44 & \text { Intervertebral disc lesion } & 21 \\ 65 & \text { Osteoarthritis of hip } & 15 \\ 18 & \text { Tenosynovitis of wrist } & 21 \\ 20 & \text { Postural backache } & 25 \\ 50 & \text { Lumbar spondylosis } & 84 \\ 19 & \text { Postural backache } & 9 \\ 18 & \text { Postural backache } & 7 \\ 26 & \text { Postural backache } & 11\end{array}$

had received phenylbutazone three years previously; otherwise no patient had received the drug before. Initially, $\mathbf{4 0 0} \mathrm{mg}$. was given orally in two divided doses; in patients $1,2,3,4$, and 7 this was reduced to $100 \mathrm{mg}$. three times daily after the first two days. The patients 
were instructed to take the tablets immediately after meals.

The duration of treatment varied. It was not considered justifiable to continue the use of a potentially dangerous drug when a discernible therapeutic effect was not produced in one to three weeks. The drug was stopped in patient 1 after one week because of an erythematous rash, after 11 days in patient 9 because the patient complained of epigastric discomfort, and after 84 days in patient 6 because of the development of oedema.

A second group of six patients was then studied (Table II). Each was given either $\mathbf{3 0 0} \mathrm{mg}$. or $\mathbf{4 0 0} \mathrm{mg}$. of phenyl-

TABLE II

PATIENTS TREATED WITH PHENYLBUTAZONE AND ANTRENYL

\begin{tabular}{|c|c|c|c|c|}
\hline & $\begin{array}{l}\text { Age } \\
\text { in } \\
\text { Years }\end{array}$ & Sex & Diagnosis & $\begin{array}{l}\text { Duration } \\
\text { of } \\
\text { Treatment } \\
\text { (Days) }\end{array}$ \\
\hline $\begin{array}{l}\text { Patient } 10 \text { (A.D.) } \\
\text { Patient } 11 \text { (E.M.) }\end{array}$ & $\begin{array}{l}65 \\
60\end{array}$ & $\begin{array}{l}\mathbf{F} \\
\mathbf{F}\end{array}$ & $\begin{array}{l}\text { Osteoarthritis of hip } \\
\text { Generalized osteo- } \\
\text { arthritis }\end{array}$ & $\begin{array}{l}14 \\
14\end{array}$ \\
\hline $\begin{array}{l}\text { Patient } 12 \text { (F.H.) } \\
\text { Patient } 13 \text { (T.B.) } \\
\text { Patient } 14 \text { (F.W.) } \\
\text { Patient } 15 \text { (E.T.) }\end{array}$ & $\begin{array}{l}74 \\
30 \\
28 \\
66\end{array}$ & $\begin{array}{l}\mathbf{M} \\
\mathbf{F} \\
\mathbf{M} \\
\mathbf{F}\end{array}$ & $\begin{array}{l}\text { Lumbar spondylosis } \\
\text { Polyarthritis? cause } \\
\text { Reiter's syndrome } \\
\text { Rheumatoid arthritis }\end{array}$ & $\begin{array}{r}14 \\
7 \\
7 \\
14\end{array}$ \\
\hline
\end{tabular}

butazone daily for one to two weeks, and in addition an anticholinergic drug. The anticholinergic drug used was oxyphenonium bromide (Antrenyl), $5 \mathrm{mg}$. being administered orally four times daily. These patients also received magnesium trisilicate powder, $4 \mathrm{ml}$. three times daily after meals.

In both groups plasma pepsinogen activity was measured twice before the drug was started and at

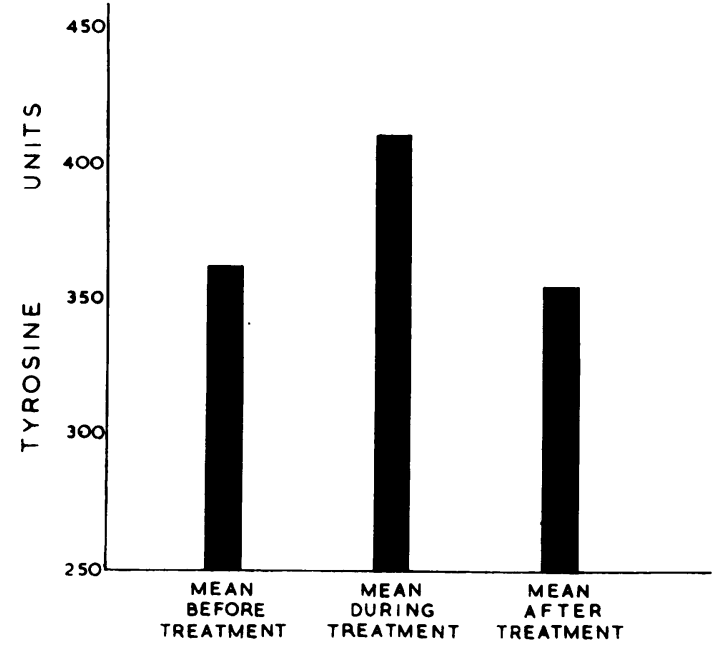

FIG. 1. Average values for nine patients receiving phenylbutazone alone (baseline $=250$ units).

intervals during treatment. Blood was taken at the same time on each day to avoid possible diurnal variations, and the plasma was stored at $-15^{\circ} \mathrm{C}$.

Mirsky's modification of Ansen's method of estimating tyrosine substances formed during enzymatic proteolysis was used (Mirsky, Futterman, Kaplan, and Broh-Kahn, 1952; Hoar and Browning, 1956). A series of standard solutions of tyrosine was included in each assay, as the Folin-Ciocalteau colour reaction is not constant. A Hilger absorptiometer as used by Nolan (1958) was used at a wave length of $430 \mu$. Results are expressed in tyrosine

TABLE III

PATIENTS TREATED WITH PHENYLBUTAZONE ALONE

\begin{tabular}{|c|c|c|c|c|c|c|c|c|c|c|c|c|}
\hline Patient & & & 1 & 2 & 3 & 4 & $j$ & 6 & 7 & 8 & 9 & $\begin{array}{l}\text { Mean for } 9 \\
\text { Cases }\end{array}$ \\
\hline $\begin{array}{l}\text { Before } \\
\text { butazolidin } \\
\text { Mean before }\end{array}$ & $\begin{array}{l}\text { Day } \\
\text { Day }\end{array}$ & $\begin{array}{l}1 \\
2\end{array}$ & $\begin{array}{l}400 \\
380 \\
390\end{array}$ & $\begin{array}{l}320 \\
305 \\
312 \cdot 5\end{array}$ & $\begin{array}{l}480 \\
440 \\
460\end{array}$ & $\begin{array}{l}290 \\
295 \\
292 \cdot 5\end{array}$ & $\begin{array}{l}320 \\
280 \\
300\end{array}$ & $\begin{array}{l}300 \\
270 \\
285\end{array}$ & $\begin{array}{l}290 \\
340 \\
315\end{array}$ & $\begin{array}{l}310 \\
400 \\
355\end{array}$ & $\begin{array}{l}570 \\
520 \\
545\end{array}$ & $361 \cdot 6$ \\
\hline $\begin{array}{l}\text { During } \\
\text { butazolidin }\end{array}$ & Day & $\begin{array}{r}3 \\
4 \\
5 \\
6 \\
7 \\
8 \\
9 \\
11 \\
14 \\
15 \\
21 \\
52 \\
84\end{array}$ & $\begin{array}{l}400 \\
500 \\
475\end{array}$ & $\begin{array}{l}345 \\
475 \\
400 \\
350 \\
380 \\
310\end{array}$ & $\begin{array}{l}540 \\
480 \\
520\end{array}$ & $\begin{array}{l}330 \\
400 \\
310\end{array}$ & $\begin{array}{l}390 \\
370 \\
430\end{array}$ & $\begin{array}{l}340 \\
410 \\
450 \\
280 \\
416\end{array}$ & $\begin{array}{l}350 \\
330\end{array}$ & 410 & $\begin{array}{l}565 \\
620 \\
500\end{array}$ & \\
\hline Mean during & & & 458 & 377 & 495 & 334 & 400 & 416 & 340 & 410 & 557 & $411 \cdot 2$ \\
\hline $\begin{array}{l}\text { After } \\
\text { butazolidin } \\
\text { Mean after }\end{array}$ & & $\begin{array}{l}1 \\
2\end{array}$ & $\begin{array}{l}355 \\
350 \\
352 \cdot 5\end{array}$ & $\begin{array}{l}300 \\
320 \\
310\end{array}$ & $\begin{array}{l}- \\
-\end{array}$ & $\begin{array}{l}300 \\
300\end{array}$ & $\begin{array}{l}290 \\
290\end{array}$ & $\begin{array}{l}380 \\
380\end{array}$ & $\begin{array}{l}260 \\
260\end{array}$ & $\begin{array}{l}390 \\
390\end{array}$ & $\begin{array}{l}550 \\
550\end{array}$ & $\begin{array}{l}354 \cdot 5 \\
\text { (For } 8 \text { cases) }\end{array}$ \\
\hline
\end{tabular}



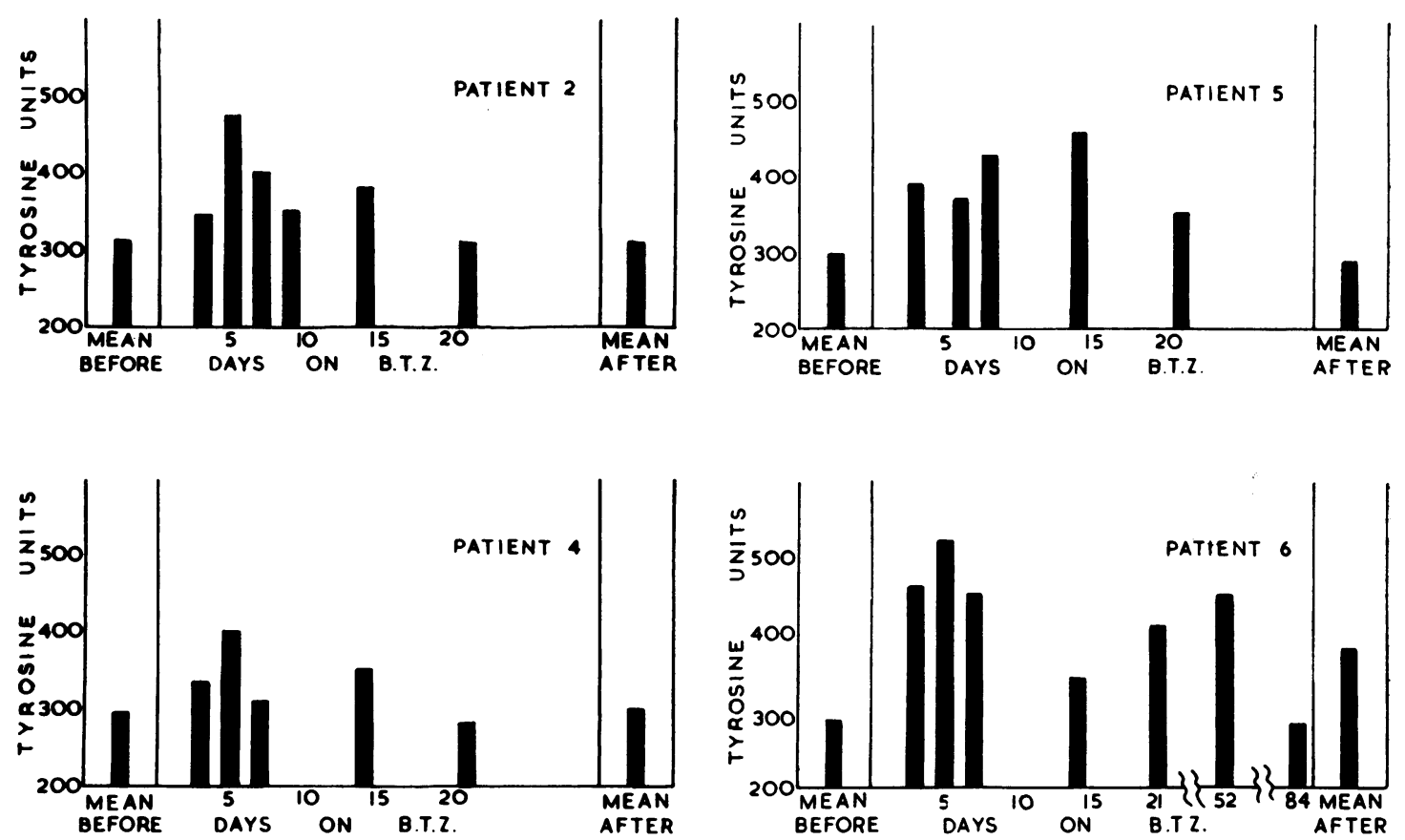

FIG. 2. The effect of phenylbutazone on plasma pepsinogen activity in patients 2 and 4 (baseline $=200$ units).

units, equivalent to microgrammes of tyrosine released per millilitre of plasma. The variation between duplicate estimations was found to be less than $7 \%$.

\section{RESULTS}

The results in the first nine patients are shown in Table III and illustrated in Fig. 1. In all cases pepsinogen activity rose during treatment. The difference between the mean before and during treatment is highly significant $(P=0.001)$. After treatment the values fell to pre-treatment levels.

Table III also shows that there was a tendency for the values to be highest during the first week of

FIG. 3. The effect of phenylbutazone on plasma pepsinogen activity in patients 5 and 6 (baseline $=200$ units).

treatment. Thereafter they tended to fall towards pre-treatment levels in spite of a constant intake of phenylbutazone. The results in the four patients who were most completely studied over long periods are shown diagramatically in Figs. 2 and 3.

The results in the patients in the second group are shown in Table IV. Plasma pepsinogen activity rose in patients $10,11,13$, and 15 , despite the administration of an anticholinergic drug.

\section{DISCUSSION}

It has been recorded that epigastric discomfort and ulcer complications induced by phenylbutazone

TABLE IV

PATIENTS TREATED WITH PHENYLBUTAZONE AND ANTRENYL

\begin{tabular}{|c|c|c|c|c|c|c|c|c|}
\hline Patient & & 10 & 11 & 12 & 13 & 14 & 15 & $\begin{array}{l}\text { Mean for } 6 \\
\text { Cases }\end{array}$ \\
\hline $\begin{array}{l}\text { Before } \\
\text { butazolidin } \\
\text { Mean before }\end{array}$ & $\begin{array}{ll}\text { Day } 1 \\
\text { Day } 2\end{array}$ & $\begin{array}{l}180 \\
190 \\
185\end{array}$ & $\begin{array}{l}310 \\
290 \\
300\end{array}$ & $\begin{array}{l}300 \\
290 \\
295\end{array}$ & $\begin{array}{l}235 \\
245 \\
240\end{array}$ & $\begin{array}{l}400 \\
450 \\
425\end{array}$ & $\frac{270}{270}$ & 285.8 \\
\hline $\begin{array}{l}\text { During } \\
\text { butazolidin }\end{array}$ & Day $\begin{array}{r}3 \\
5 \\
7 \\
14\end{array}$ & $\begin{array}{l}190 \\
290 \\
220 \\
250 \\
237 \cdot 5\end{array}$ & $\begin{array}{l}350 \\
360 \\
330 \\
370 \\
352 \cdot 5\end{array}$ & $\begin{array}{l}220 \\
290 \\
300 \\
270 \\
270\end{array}$ & $\begin{array}{l}250 \\
320 \\
150 \\
-\overline{273} \cdot 3\end{array}$ & $\begin{array}{l}460 \\
320 \\
370 \\
\overline{383 \cdot 3}\end{array}$ & $\begin{array}{l}330 \\
420 \\
275 \\
360 \\
346 \cdot 25\end{array}$ & 310.5 \\
\hline
\end{tabular}

Plasma pepsinogen activity expressed as tyrosine units released per $\mathrm{ml}$. of plasma. 
occur most frequently early in the course of treatment (Kelly, 1954; Mauer, 1955). In one group of 35 patients with these side-effects, 23 developed symptoms in the first week (Freeland, Storey, and Thompson, 1953). Less commonly ulcer symptoms may develop after months of treatment. Reactions have also occurred after the drug has been withdrawn, and in this connexion it is interesting that phenylbutazone remains in the blood for 10 to 21 days after cessation of treatment (Bruck, Fearnley, Meanock, and Patley, 1954). The results recorded here, showing a peak rise in plasma pepsinogen activity during the first week of administration of phenylbutazone with a subsequent fall, may be relevant to the clinical observation of the time of greatest frequency of these gastrointestinal sideeffects.

To draw more specific conclusions from these results depends on the interpretation of the relationship between levels of plasma pepsinogen activity and gastric function. The exact relation between peptic cell activity and plasma pepsinogen activity is uncertain. There is a virtual absence of pepsinogen activity in plasma and urine following total gastrectomy and in cases of pernicious anaemia (Chinn, 1953; Hirschowitz, 1955). Conversely, gastric pepsin secretion and plasma pepsinogen activity are both significantly higher in patients with duodenal ulcer than in normal persons (Chinn, 1953; Van Goidsenhoven, Wilkoff, and Kirsner, 1958). In addition, significant correlations have been shown between gastric pepsin and plasma pepsinogen activity in normal people by Janowitz, Levy, and Hollander, (1950) and Van Goidsenhoven et al. (1958).

Hirschowitz (1957) has stressed the constancy of plasma pepsinogen activity despite such stimuli as food, insulin, and anticholinergic drugs, all of which modify gastric pepsin secretion. He does not believe that the plasma activity gives a reliable indication of the secretory activity of the stomach. Goidsenhoven has, however, pointed out that the general pool of pepsinogen in the body may be quite large and it may therefore take some time for stimuli to affect the plasma activity. Thus, starvation for 24 to 48 hours and a similar duration of treatment with anticholinergic drugs is necessary to decrease plasma activity. The changes reported here may therefore reflect increased peptic cell activity.

An alternative explanation for our findings is suggested by an observation by Hirschowitz (1957). $\mathrm{He}$ found that plasma pepsinogen activity is increased by procedures which damage the gastric mucosa, such as destructive doses of histamine in dogs and guinea-pigs. He suggested that the rise in plasma pepsinogen in these circumstances was analagous to the rise in plasma of pancreatic enzymes following acute pancreatitis. It is possible, therefore, that the early rise in plasma pepsinogen activity which follows administration of phenylbutazone may reflect damage to the stomach rather than a change in secretory activity, and this possibility merits further study.

I am grateful to Dr. Sara Weiden for her help with the biochemical methods, to Dr. R. H. Melick for helpful criticism, and to Dr. K. J. Grice for permission to study patients under his care. I am also indebted to Professor R. R. H. Lovell for suggesting the investigation and for his encouragement.

\section{REFERENCES}

Bellomo and Fusco (1956). Foreign Letters; J. Amer. med. Ass., 161, 173.

Bruck, E., Fearnley, M. E., Meanock, I., and Patley, H. (1954). Lancet, 1, 225-228.

Chinn, A. B. (1953). Gastroenterology, 25, 14-23.

Dilling, N. V. (1953). Lancet, 1, 1230-1231.

Freeland, D., Storey, G., and Thompson, N. (1953). Ibid, 1, 1227 1229.

Hirschowitz, B. I. (1955). J. Lab. clin. Med., 46, 568-579.

(1957). Physiol. Rev., 37, 475-511.

Hoar. C. S. Jr., and Browning, J. R. (1956). New Engl. J. Med., 255, 153-158.

Janowitz, H. D., Levy, M., and Hollander, F. (1950). Amer. J. med. Sci., 220, 679-682.

Kelly, M. (1954). Med. J. Aust., 2, 504-507.

Kirsner, J. B. (1957). Ann. intern. Med., 47, 666-699.

- , and Ford, H. (1955). Gastroenterology, 29, 1-17.

Kuzell, W. C., Schaffarzick, R. W., Naugler, W. E., Gaudin, G., and Mankle, E. A. (1953). A.M.A. Arch. intern Med., 92, 646-661.

Mauer, E. F. (1955). New Engl. J. Med., 253, 404-410.

Mirsky, A., Futterman, P., Kaplan, S., and Broh-Kahn, R. H. (1952). J. Lab. clin. Med., 40, 17-26.

Nolan, K. E. (1958). Med. J. Aust., 2, 831-833.

Van Goidsenhoven, G., Wilkoff, L., and Kirsner, J. B. (1958). Gastroenterology, 34, 421-435. 